This is a self-archived version of an original article. This version may differ from the original in pagination and typographic details.

Author(s): Backman, Jussi

Title: Encountering Finitude : On the Hermeneutic Radicalization of Experience

Year: 2018

Version: Accepted version (Final draft)

Copyright: ㄷ Brill, 2018.

Rights: In Copyright

Rights url: http://rightsstatements.org/page//nC/1.0/?language=en

Please cite the original version:

Backman, J. (2018). Encountering Finitude : On the Hermeneutic Radicalization of Experience. In A. Cimino, \& C. Leijenhorst (Eds.), Phenomenology and Experience : New Perspectives (pp. 46-62). Brill. Studies in Contemporary Phenomenology, 18.

https://doi.org/10.1163/9789004391031_005 
This is the submitted version of a chapter published in Phenomenology and Experience: New Perspectives, edited by Antonio Cimino and Cees Leijenhorst (Leiden: Brill, 2018), 4662, available online at https://doi.org/10.1163/9789004391031 005.

\title{
Encountering Finitude: On the Hermeneutic Radicalization of Experience
}

\author{
Jussi Backman
}

\section{The perils of experience}

"However paradoxical it may seem," Hans-Georg Gadamer writes in Truth and Method, "the concept of experience [Erfahrung] seems to me one of the most unelucidated [unaufgeklärtesten] concepts we have." 2

Indeed, the claim is striking. After all, few terms have been more central to the Western epistemological tradition, which, ever since Aristotle, has conceived of experience as an indispensable stage in the ascent to comprehensive knowledge and understanding. With the increasing doubts that late medieval and early modern philosophy cast upon the capacity of discursive reason to penetrate the innermost essence of nature on its own strength, experience emerged as the watchword with which modern science distinguished itself from the Aristotelian model of epistèmé, which is focused on intuitive insight and deductive reasoning. In his manifesto for an experimental scientific method, Novum Organum (1620), Sir Francis Bacon describes the incipient modern age as an age of experience (experientia), one in which "the store of experiences has grown immeasurably" in comparison to antiquity, with its greatly expanded perspective on history, unforeseen technical innovations, and the

\footnotetext{
${ }^{1}$ For valuable comments, I would like to thank Anniina Leiviskä and Harri Mäcklin. For financial support, I am grateful to the Academy of Finland research project The Intellectual Heritage of Radical Cultural Conservatism. ${ }^{2}$ Hans-Georg Gadamer, Wahrheit und Methode: Grundzüge einer philosophischen Hermeneutik [1960], Gesammelte Werke, vol. 1 (Tübingen: Mohr Siebeck, 1990), 352; Truth and Method, trans. Joel Weinsheimer and Donald G. Marschall, 2nd ed. (London: Continuum, 2004), 341. Translation modified.
} 
discovery of the New World and its peoples. ${ }^{3}$ Since Bacon and the British Empiricists, the emphasis on experience as the foundation of human knowledge has reverberated throughout modern philosophy. Kant begins the introduction to the second edition of his first Critique by stating: "There is no doubt whatever that all our cognition [Erkenntnis] begins with experience [Erfahrung]"-even though, he adds, this is so only in the chronological order, not in the sense that all knowledge would derive from experience. ${ }^{4}$ Hegel's Phenomenology of Spirit, intended as the first part of his absolute system of science, is the "science of the experience of consciousness." 5 For Husserl, one of the last representatives of this classical modern tradition, the lifeworld (Lebenswelt) in which we are "always already living and which furnishes the ground for all cognitive performance and all scientific determination," is precisely the "world of experience."6

Nonetheless, according to Gadamer, the full implications of the concept of experience have remained insufficiently elucidated, due to a one-sided "epistemological schematization that . . . truncates its original content." 7 The Western philosophical tradition has considered experience in a teleological framework as a means to an end, as a faculty from which knowledge and truth can be extracted through the proper implementation of a scientific method, a systematic pursuit (methodos) of higher forms of knowing. ${ }^{8}$ Superior knowledge can be attained only when the inherent shortcomings of "raw" or "ordinary" experience are overcome through proper methodical discipline. For Gadamer, this methodical drive towards overcoming the vicissitudes, the risks and perils of experience, is, to a certain extent, inherent in the nature of experiencing itself: experience "naturally" seeks repetition, confirmation, and certainty in order to consolidate itself and restrict the possibility of further, unpredictable experience. We learn from experience when, through our encounters with

${ }^{3}$ Francis Bacon, Novum Organum [1620], ed. Thomas Fowler, 2nd ed. (Oxford: Clarendon Press, 1889); The New Organon, ed. Lisa Jardine and Michael Silverthorne (Cambridge: Cambridge University Press, 2000), 1.72.

${ }^{4}$ Immanuel Kant, Kritik der reinen Vernunft [1781/1787], ed. Jens Timmermann (Hamburg: Meiner, 1998), 43; Critique of Pure Reason, trans. Paul Guyer and Allen W. Wood (Cambridge: Cambridge University Press, 1998), 136 [B 1].

${ }^{5}$ G. W. F. Hegel, Phänomenologie des Geistes [1807], ed. Wolfgang Bonsiepen and Reinhard Heede, Gesammelte Werke, vol. 9 (Hamburg: Meiner, 1980), 29, 61; Phenomenology of Mind, trans. J. B. Baillie, 2nd ed. (Mineola, NY: Dover, 2003), 20, 53.

${ }^{6}$ Edmund Husserl, Erfahrung und Urteil: Untersuchungen zur Genealogie der Logik [1939], ed. Ludwig Landgrebe, 7th ed. (Hamburg: Meiner, 1999), 38; Experience and Judgment: Investigations in a Genealogy of Logic, trans. James S. Churchill and Karl Ameriks (Evanston, IL: Northwestern University Press, 1973), 41.

${ }^{7}$ Gadamer, Wahrheit und Methode, 352; Truth and Method, 341 (trans. modified).

${ }^{8}$ Gadamer, Wahrheit und Methode, 353; Truth and Method, 342. 
things, we become prepared for what may come, that is, when the accumulation of experiences prevents further encounters from taking us by surprise. Learning can only be achieved by systematizing and synthesizing the historical multiplicity of shifting experiences into increasingly constant unities. In this sense, "by its very essence, experience merges [aufhebt] its history into itself and thus obliterates it." 9

However, it is precisely the historical multiplicity, singularity, and unpredictability of experience, which is seen as a weakness from the point of view of scientific method, that Gadamerian hermeneutics seeks to explore and elucidate. Taking our cue from several seminal texts highlighted by Gadamer himself, first and foremost, Aristotle's Metaphysics and Posterior Analytics, Bacon's Novum Organum, and Hegel's Phenomenology of Spirit, we will sketch an outline of certain key stages in the conceptual history of experience in the epistemological tradition in the coming sections. ${ }^{10}$ This will enable us to place the Heideggerian and Gadamerian hermeneutic radicalization of the concept of experience into a historical context as an attempt to overcome the limitations of the methodical approach to experience and to grasp experience anew as the finite human being's finite - that is, inherently singular and transformative, and, in that sense, risky and perilous — encounter with reality.

\section{Aristotle: experience between the particular and the universal}

The Presocratics Parmenides and Heraclitus generally depreciate experience. For them, philosophical thinking constitutes a radical break with the multiplicity of situated, particular perspectives or “acceptances" (doxa ) of ordinary "mortal” experience and entails an insight into the fundamental unity of all beings in the mode of intuitive beholding (noos) or discursive articulation (logos). ${ }^{11}$ Parmenides' goddess exhorts the thinker not to let “custom [ethos] force you upon the way of much experience [polypeiron bodon], / heeding the unregardful eye and the roaring hearing / and the tongue;

\footnotetext{
${ }^{9}$ Gadamer, Wahrheit und Methode, 353; Truth and Method, 342 (trans. modified).

${ }^{10}$ Gadamer, Wahrheit und Methode, 353-362; Truth and Method, 343-350. For more detailed and comprehensive conceptual histories of experience, see Fritz-Peter Hager, "Empeiria," in Historisches Wörterbuch der Philosophie, vol. 2, ed. Joachim Ritter (Basel: Schwabe, 1972), 453-454; Friedrich Kambartel, "Erfahrung," in Historisches Wörterbuch der Philosophie, vol. 2, 609-617.

${ }^{11}$ Jussi Backman, "Towards a Genealogy of the Metaphysics of Sight: Seeing, Hearing, and Thinking in Heraclitus and Parmenides," in Phenomenology and the Metaphysics of Sight, ed. Antonio Cimino and Pavlos Kontos (Leiden: Brill, 2015), 9-34.
} 
rather, discern through discursive articulation [krinai . . logö]." 12 Plato, too, mainly views empeiria in a derogatory manner, as a mere business or occupation (epitédeusis, tribe) , such as rhetoric, that does not constitute an art (techne) based on rational insight but rather requires proficiency acquired through mere habituation. ${ }^{13}$

Aristotle, however, takes a different approach. For him, there is a relationship of continuity between experience and rational insight. In his genealogy of human knowledge and understanding in the first book of the Metaphysics and in the Posterior Analytics, Aristotle describes empeiria as the point of divergence between the cognitive capacities of the human being and those of nonhuman animals. Animals are distinguished from plants by sense perception (aisthèsis), the innate capacity for apprehending their environment through the senses; some animals further possess memory (mnème), that is, the ability to retain sensations beyond the immediate act of perceiving them. ${ }^{14}$ Of the animals that remember, some (first and foremost, humans) are further capable of discursively articulating their sensations with the help of a conceptual determination (logos), which then allows them to identify certain perceptions as sharing one and the same object with previous perceptions retained in memory. ${ }^{15}$ It is this latter perception of identity, the attainment of a "universal [katholou] that has come to rest in its entirety in the soul, a unity that is apart from the many [retained sensations] and is present in all of them as one and the same," that grounds experience (empeiria). ${ }^{16}$

Experience is, for Aristotle, an essentially discursive capacity for accumulating propositions (bypolēpseis) regarding particular cases (kath' hekaston) with some degree of identity. Experience tells us, for example, that patient A with a certain kind of ailment benefited from a certain treatment and that this was also the case for patients $\mathrm{B}$ and $\mathrm{C}$ with similar ailments, which then encourages us to apply the same treatment in the similar case of patient D. ${ }^{17}$ The sufficient accretion of such individual experiences finally allows us to move to a new level of abstraction, formulating a general rule-for example, that treatments of a certain type will benefit a certain type of patients with certain symptoms. This step from habitual familiarity to the possession of a universal principle is the step

\footnotetext{
${ }_{12}$ Parmenides, DK 28 B 7.3-5, in Hermann Diels and Walther Kranz, Die Fragmente der Vorsokratiker, vol. 1, 6th ed. (Berlin: Weidmann, 1951).

${ }^{13}$ Plato, Gorgias, in Platonis opera, vol. 3, ed. John Burnet (Oxford: Clarendon Press, 1903), 462b10-463b4.

${ }_{14}$ Aristotle, Metaphysics, vol. 1, ed. W. D. Ross (Oxford: Clarendon Press, 1924), 1.1.980a27-b25; Posterior Analytics, in Analytica priora et posteriora, ed. W. D. Ross (Oxford: Clarendon Press, 1964), 2.19.99b32-100a1.

${ }^{15}$ Aristotle, Posterior Analytics 2.9.100a1-3, 15-b1.

${ }^{16}$ Aristotle, Posterior Analytics 2.19.100a3-8; cf. Metaphysics 1.1.980b25-981a1, 5-7.

${ }_{17}$ Aristotle, Metaphysics 1.1.981a7-9.
} 
from experience to technè, technical expertise or "art." ${ }^{18}$ What distinguishes the expert or master craftsperson (architektōn) possessing techne from the experienced worker (cheirotechnēs), whose hability is an incommunicable "manual" routine (ethos) acquired by doing, is the former's insight into formal principles and her ability to teach her expertise (verbally and discursively) to others. ${ }^{19}$

Experience is thus the necessary preliminary to the more comprehensive, discursive, and systematic forms of knowledge constituted through the human soul's natural capacity to discursively synthesize and articulate sensations and to abstract from them more and more comprehensive conceptual unities. Aristotle is no empiricist in the modern sense: even though sense perception and the accumulation of experience necessarily precede in time the higher, more abstract levels of knowledge concerning the ideal structures of reality, such knowledge is not reducible to individual perceptions. For the Aristotelian tradition, "induction," epagōgè, does not mean simply the logical derivation of the universal from particular cases, but more generally the literal "guidance," the agogge or ductio, provided by experience of particulars toward an intuitive grasp of the universal. ${ }^{20}$

We thus find in the Aristotelian account a teleological and methodological instrumentalization of experience as a pathway to a level of certainty and necessity that is itself, in some sense, beyond experience. For Aristotle, the important epistemological limitation of experience in the ordinary sense is its contingency, its dependence on random individual encounters with particular phenomena. Experience is exclusively awareness of facts, of the bare contingent "that" (to hoti), without their underlying principles or grounds, the "because" (dioti). ${ }^{21}$ Knowledge, however, cannot be satisfied with the contingent. Philosophy as a theoretical project starts from wonder (thaumazein), inspired by things that happen to be at hand (ta procheira), but ultimately seeks the grounds of everything that there is. ${ }^{22}$ The path of knowledge must thus lead from sensible particulars, "better known and more evident to us" in the genealogical and developmental order, to the most universal determinations,

\footnotetext{
${ }_{18}$ Aristotle, Metaphysics 1.1.981a1-12.

${ }_{19}$ Aristotle, Metaphysics 1.1.981a12-b10.

${ }^{20}$ Aristotle, Topics, in Topica et Sophistici elenchi, ed. W. D. Ross (Oxford: Clarendon Press, 1958), 1.12.105a1316, 18.108b9-11; cf. Physics, ed. W.D. Ross (Oxford: Clarendon Press, 1936), 1.2.185a12-14. Cf. Posterior Analytics 2.5.91b34-35: "For the one who shows something by induction [epagōn] does not demonstrate by argument [apodeiknysin], but, nonetheless, makes something evident [dēloi]." See also Rudolf Ružička, "Induktion I," in Historisches Wörterbuch der Philosophie, vol. 4, ed. Joachim Ritter and Karlfried Gründer (Basel:
} Schwabe, 1976), 323-329.

${ }^{21}$ Aristotle, Metaphysics 1.1.981a24-30.

${ }^{22}$ Aristotle, Metaphysics 1.2.982b11-28. 
"better known and more evident in the order of nature." In Kantian terms, this refers to that which is known after the fact, a posteriori, to that which is known before all facts, a priori, and is necessarily true regardless of the situation. ${ }^{23}$

\section{Bacon: From experience to experiment}

The Aristotelian understanding of experience held sway throughout the Aristotelian tradition up to Thomas Aquinas. ${ }^{24}$ It is not until early modernity that an upheaval in the status of experience takes place. The important philosophical difference between the Aristotelian and the early modern thinkers was that the latter had largely, if often implicitly, accepted the consequences of the theological voluntarism of the late medieval via moderna, represented in various forms by scholastics such as John Duns Scotus, William of Ockham, and Gabriel Biel. Voluntarists saw the rational, moral, and physical order of created nature, to which God's “ordained power" (potentia ordinata) has normally been committed since creation, as ultimately contingent and constantly capable of being overridden by God's exercise of the primordial absolute freedom of his will, his absolute power (potentia absoluta). ${ }^{25}$

${ }_{23}$ Aristotle, Physics 1.1.184a16-21; Posterior Analytics 1.2.71b29-72a5. Note, however, that while according to the Posterior Analytics, what is closest to us are sensible particulars, from which we proceed toward universals, in the Physics (1.1.184a21-b14), Aristotle states that what we actually initially encounter in sense perception is a confused and indeterminate general notion (e.g., "animal") which is then defined and analyzed into more specific kinds (horses, cows etc.). The latter description fits Aristotle's historical account of the development of philosophy in the first book of Physics as the emergence of increasingly sophisticated conceptual distinctions. Both accounts stress that knowledge essentially strives for a grasp of the causes (aitia) and principles (archai) of things, which are universals in the true sense of the word. Bacon (Novum Organum 1.19, 1.104) criticizes the Aristotelian method precisely for leaping too quickly over the passage from particulars to universals, which for him is the only true path of science.

24 Thomas Aquinas, for example, simply reiterates Aristotle's definition of experience (experientia) as a synthesis of many remembrances; Thomas Aquinas, Summa Theologiae, Pars Prima, Quaestiones L-CXIX, Sancti Thomae Aquinatis opera omnia, vol. 5 (Rome: Polyglotta, 1889), 1.58.3.

${ }^{25}$ See William J. Courtenay, "Potentia absoluta/ordinata," in Historisches Wörterbuch der Philosophie, vol. 7, ed. Joachim Ritter and Karlfried Gründer (Basel: Schwabe, 1989), 1157-1162. For this thesis concerning the influence of the Christian doctrine of creation and its radicalization in late medieval philosophy on the foundations of modern empirical science, see, e.g., Michael B. Foster, "The Christian Doctrine of Creation and the Rise of Modern Natural Science," Mind 43 (1934): 446-468; Francis Oakley, "Christian Theology and the Newtonian Science: The Rise of the Concept of Laws of Nature," Church History 30 (1961): 433-457. For a critical 
This approach was closely linked to the nominalist ascription of a purely intramental existence to the forms and structures of human understanding, which have gradually become "ideas" in the modern sense. ${ }^{26}$

With these theological and metaphysical views operating in their background, the early moderns were beset by a new skepticism: they could no longer simply regard natural philosophy as a straightforward matter of discovering, by means of reason alone, immediately accessible rational principles inherent in nature itself. For Descartes, who considers even mathematical truths to be contingent upon the divine will, there is a plausible danger that the workings of our created reason are inherently distorted. ${ }^{27}$ In order to avert this risk, our reason has to be provided with a guarantee: indubitable proof of the existence of God as a perfect being who would not will to deceive our reason as long as it operates with the simple, clear, and distinct ideas placed in it by its creator. ${ }^{28}$ The British empiricists will, of course, accept the same general predicament of reason-that it is not in a position to claim direct access to the "mind of God" and the intelligible foundations of his creation-but go on to reject the Cartesian way out, denying the existence of pregiven necessary ideas in the human mind, famously viewed by Locke in its initial state as "white paper, void of all characters." According to Locke, whatever ideas arise in the mind are to be regarded as the result of experience, which he understands in a general and vague sense comprising the mind's individual sensory encounters with

modification of this view, emphasizing that not only early modern empiricism but equally the rationalism of Descartes was based on the voluntarist understanding of the primacy of the divine will, see Peter Harrison, "Voluntarism and Early Modern Science," History of Science 40 (2002): 63-89. Cf. John Henry, "Voluntarist Theology at the Origins of Modern Science: A Response to Peter Harrison," History of Science 47 (2009): 79-113. ${ }^{26}$ On the emergence of the modern concept of "idea," first and foremost introduced by Descartes, see Wilhelm Halbfass, “Idee III,” in Historisches Wörterbuch der Philosophie, vol. 4, 102-113.

${ }^{27}$ In his letter of April 15, 1630 to Marin Mersenne, Descartes defends the view that even "eternal" truths, such as those of mathematics, were created by God because he willed thus; René Descartes, Correspondance avril 1622 - février 1638, ed. Charles Adam and Paul Tannery, Euvres, vol. 1 (Paris: Vrin, 1897), 145-146; The Correspondence, trans. John Cottingham et al., The Philosophical Writings of Descartes, vol. 3 (Cambridge: Cambridge University Press, 1991), 23. The famous hypothetical "evil demon" argument regarding the possibility of complete deception is presented in Descartes's First Meditation; Meditationes de prima philosophia [1641], ed. Charles Adam and Paul Tannery, Cuvres, vol. 7 (Paris: Vrin, 1904), 20-23; Meditations on First Philosophy, trans. John Cottingham, Robert Stoothoff, and Dugald Murdoch, The Philosophical Writings of Descartes, vol. 2 (Cambridge: Cambridge University Press, 1984), 14-15.

${ }_{28}$ This proof is given in the Third, Fourth, Fifth, and Sixth Meditations; Descartes, Meditationes, 34-90; Meditations, 24-62. 
reality, its reflective encounters with itself, as well as the imprints and lasting syntheses produced in the mind by these encounters. ${ }^{29}$

The first outline of what developed into the modern scientific method was famously drawn by Sir Francis Bacon in his Novum Organum (1620) - a work purporting to present a "new organon," a new "instrument" or methodology of science to replace the "old organon" of Aristotle's logic and forming part of Bacon's unfinished overarching project Instauratio Magna, the "great renewal" of science. The aim of his new logic of scientific inquiry, Bacon declares in his dedicatory letter to King James I, is to ensure that "after so many ages of the world" without adequate progress, science and philosophy will no longer "float in the air, but rest upon the solid foundations of every kind of experience [experientiae] properly considered." 30 In their modern rebirth (regeneratio) envisioned by Bacon, the sciences will be "raised up in a sure order from experience and founded anew, which no one ... would affirm has yet been done or contemplated."31

Like his younger contemporary Descartes, Bacon emphasizes the distance between human notions and the ideas of the divine mind according to which the true essences or forms of things are created. ${ }^{32}$ Only God has immediate access to these forms; we finite beings must discover them gradually and incompletely through the study of nature. ${ }^{33}$ Such a study should not attempt to simply leap from the particulars of experience to intuitive and abstract axioms of reason, as Bacon accuses traditional (Aristotelian) induction of doing. The Aristotelian method has resulted in a natural philosophy that is basically a mere self-reflection of the human mind on its own vague and deficient concepts and, for the most part, simply "voices dialectical terms." ${ }_{4}$ Its basic fault is to regard the constitution of knowledge as a natural process to which the human mind is inherently suited. Rather, Bacon maintains, certain innate tendencies and inclinations of the human mind hamper and distort its access to nature. These are the four famous "idols" or "illusions" (idola) of our reason, which are related to the inherent limitations of the human sensory and cognitive capacities, the specific situatedness of the individual human being, the limits imposed by the shared language and discourse

\footnotetext{
${ }^{29}$ John Locke, An Essay Concerning Human Understanding [1689], ed. Peter H. Nidditch (Oxford: Clarendon Press, 1975), 104 [2.1.2].

30 Bacon, Novum Organum, dedicatory letter.

31 Bacon, Novum Organum 1.97.

32 Bacon, Novum Organum 1.23.

${ }^{33}$ Bacon, Novum Organum 2.15.

${ }^{34}$ Bacon, Novum Organum 1.63, 1.104.
} 
of human communities, and misleading intellectual doctrines and traditions. ${ }^{35}$ The different prejudices arising from these tendencies must be acknowledged and obliterated in order to gain access to the hidden truths of creation.

Thus, experience in itself does not guide us toward higher forms of knowing, but must first be subjected to a systematic and methodical procedure. Our ordinary mode of experiencing, Bacon argues, is "blind and stupid," errant and wandering in that it takes its lead from mere random encounters with things (ex occursu rerum): the objects of further investigation are simply come across (inveniunt) in a casual manner. ${ }^{36}$ This leaves knowledge to the "waves and winding of chance [casus] and casual, unregulated experience [experientiae vagae et inconditae]." Dependence on experiences that merely occur by chance is like groping around in the dark in hopes of stumbling upon the right path. Experience must be undiluted by human idols, but not passive; in addition to actively purging our own understanding of hindrances, we must also take an active stance towards nature. The student of nature must interrogate nature, pose questions to it. Only experience that is actively sought after, "requested" (quaesita), deserves the name of "experiment" (experimentum). ${ }^{37}$ Bacon likens such active, productive experiencing to the divine act of creation: just as God created light before any determinate thing, scientific inquiry must be illuminated by the light of the proper "experimental" method that eliminates randomness and contingency before embarking on particular experiments. ${ }^{38}$

Methodical experimenting allows us to overcome the great inherent weakness of experience: the uncertainty and fallibility due to the constant possibility of a negative experience. Bacon is fully aware of this negative dimension of experience and its importance with regard to the inherent bias of the mind in favor of positive instances that confirm prejudices and superstitions. ${ }^{39}$ However, in order to extract positive results from experience, this negativity must be appropriately managed. The manifest problem with inductive reasoning from experience, in the traditional sense of simply enumerating instances that support a given generalization, is that it is constantly "exposed to the danger [periculo] of the contrary instance." 40 In the method elaborated by Bacon in the second book of the Novum Organum, termed "written" or "literate" experience (experientia literata), this risk is

\footnotetext{
35 Bacon, Novum Organum 1.39-69.

36 Bacon, Novum Organum 1.70.

37 Bacon, Novum Organum 1.82.

38 Bacon, Novum Organum 1.70, 1.82.

${ }^{39}$ Bacon, Novum Organum 1.46.

${ }^{40}$ Bacon, Novum Organum 1.105.
} 
controlled by a systematic separation of positive and negative instances. ${ }^{41}$ For any natural phenomenon whose nature we wish to understand (in Bacon's example, heat), we carefully draw a table of instances in which the phenomenon in question is present and another table of relevant negative cases, in which it is absent. By comparing these lists, it is ultimately possible to come up with a conjecture concerning the fundamental nature, form, or source of the phenomenon for which there is no contradictory instance. ${ }^{42}$ In this way, negative experience is systematically charted and subordinated to the attainment of positive knowledge concerning the causal laws of phenomena, which Bacon understands in terms of Aristotelian "formal causes" or essences. ${ }^{43}$

\section{Hegel: The negativity of experience}

Humean skeptical empiricism, of course, takes the danger or peril of the negative instance even more seriously than Bacon. While the latter thinks that the danger can ultimately be overcome through methodical experiencing that will allow us to map the necessary causal grounds of phenomena, Hume calls into doubt whether any observed causal regularity, no matter how strongly corroborated, can rationally entitle us to exclude the constant possibility of a contrary instance. But let us focus for a moment on the danger as such. Claude Romano draws our attention to the fact that experience (experientia) and peril (periculum) are cognates - together with a host of related words, such as the English "fear," the German Erfahrung and Gefahr "danger," and the Greek empeiria and peira "trial, attempt," they allegedly go back to the Proto-Indo-European root *per- "to try, to risk." 44 Experience, experientia, empeiria is thus literally knowledge that has undergone a peira, a risky trial or test-it is tested knowledge, "imperiled” knowledge. But what does this putting-to-the-test, this trial, consist of precisely?

In experience, it is clearly we ourselves-our knowledge and know-how, our capacity for coping with the things that face us-who are put to test. As Romano puts it, the "danger" of experience is "such that I put myself at risk in it in the first person, . . in what constitutes me

\footnotetext{
${ }^{41}$ Bacon, Novum Organum 1.101, 1.103, 1.110.

42 Bacon, Novum Organum 1.105, 2.1, 2.11-20.

${ }^{43}$ Bacon, Novum Organum 2.1-2.

${ }^{44}$ Claude Romano, L'événement et le monde (Paris: Presses Universitaires de France, 1998), 195-196; Event and World, trans. Shane McKinlay (New York: Fordham University Press, 2009), 145. On the etymology of experience, see, e.g., Calvert Watkins, ed., The American Heritage Dictionary of Indo-European Roots, 2nd ed. (Boston: Houghton Mifflin, 2000), 66.
} 
essentially as such: in my selfhood." 45 What tests and tries us in experience are precisely the singular and contingent situations in the context of which we encounter reality and are compelled to cope with it. The risk or "peril" involved in such situations is precisely the risk of failure - the risk of a negative instance in which our knowledge does not pass the test of the encounter but rather fails to cope adequately and is consequently compelled to transform and modify itself. This structure of experience through trial and error is presupposed by Aristotle as well as Bacon; and yet, as Gadamer emphasizes, the teleology inherent in their respective scientific ideals focuses not on the negativity of the test, risk, or peril as such, but rather on the positivity of its outcome, on the knowledge that, by virtue of its superior universality, ultimately survives the process of experiencing and is thus alleged to be increasingly immune to further experience, to the peril of future contingent encounters. ${ }^{46}$ For axiomatic-deductive as well as experimental-inductive science (even though the latter is, in principle, committed to empirical fallibilism, to an ultimate falsifiability of all assumptions by experience), the basic function of experience is to increasingly immunize knowledge against further experience.

This is so, Gadamer adds, even for the last great architect of a purely speculative system of science-Hegel, who lays perhaps more weight on the inherent negativity of experience than any other thinker of the tradition. The "science of the experience of consciousness" charted in The Phenomenology of Spirit is the study of the development and unfolding of the spirit (Geist) to itself as spirit, that is, as absolute subjectivity, as the fundamental self-conscious "substance" of reality. In its different developmental stages, the spirit's consciousness contains two fundamental moments: that of knowledge (Wissen) and that of the object (Gegenstand) known. The latter is "negative" with regard to knowledge in the sense that it is never completely immanent to knowledge. The experience of consciousness is, in each instance, its awareness of this disparity or opposition between its current state of knowledge and the object of this knowledge, between knowledge and truth, between the "for us" and the "in itself." 47 In other words, experience is fundamentally a negative experience of the current finitude of our knowledge.

However, against Kant's critical philosophy, Hegel presupposes that this disparity and finitude is a position in which knowledge, in its inherent will towards the absolute and the infinite, cannot and will not remain. Experience consists of testing (Prüfung) our knowledge with regard to the object; the discovery that there is more to the object than our current, inadequate cognitive grasp of it can access necessitates a dialectical movement towards a new perspective, a passage to a new stage of

\footnotetext{
${ }^{45}$ Romano, L'événement et le monde, 196; Event and World, 145.

${ }^{46}$ Gadamer, Wahrheit und Methode, 355-359; Truth and Method, 344-348.

${ }^{47}$ Hegel, Phänomenologie des Geistes, 29-30, 58-62; Phenomenology of Mind, 20-21, 50-53.
} 
consciousness in which the current disparity is resolved in an enlarged, synthetic grasp of the object that includes the prior negativity within itself. With this movement, not only knowledge but also its object and the very criterion of knowledge are transformed. ${ }^{48}$ Thus, for example, in the first dialectical step of the Phenomenology, the most elementary form of consciousness-the immediate sensory awareness of the here-and-now-is dialectically transformed into an articulate perception of a determinate object that retains its identity throughout a temporal and spatial manifold of sensations. Experience is, for Hegel, the "dialectic process which consciousness executes on itself-on its knowledge as well as its object - in the sense that out of it the new and true object arises." 49 While the inherent negativity of experience, the disparity between the conscious ego and the object of consciousness, can be regarded "as the defect [Mangel] of both opposites," it is nonetheless "their very soul, that which animates them [das Bewegende]."50

Experience is thus, for Hegel, more than knowledge encountering reality, more than simply testing knowledge with regard to something fundamentally external to it. Rather, experience is the process through which the spirit, absolute subjectivity, gradually encounters itself as spirit and tests itself. Through experience, the spirit's internal contradictions and disparities are gradually resolved as it gains a more and more comprehensive and mediated grasp of itself as the fundamental rational, discursive, conceptual, and ideal structure of reality. At the end of this process stands the spirit's complete reconciliation with itself: absolute knowledge, a purely positive perspective of the spirit upon itself that leaves no residual disparity or negativity, and consequently, no room for further experience. The experience of consciousness culminates in the impossibility of further experience in the strict sense. On this absolute level of knowledge, the remaining task in the system of absolute science is the elaboration of the conceptual architecture of the discursive contents of knowledge, a task that is performed by the purely speculative science of logic. ${ }^{51}$

\section{Hermeneutic experience as experience of finitude}

In his 1942-43 reading of the Introduction to The Phenomenology of Spirit, Heidegger highlights the way in which Hegel's concept of experience is determined by the absolute teleology of his dialectic, which

\footnotetext{
${ }^{48}$ Hegel, Phänomenologie des Geistes, 59-60; Phenomenology of Mind, 51.

${ }^{49}$ Hegel, Phänomenologie des Geistes, 60; Phenomenology of Mind, 51.

${ }^{50}$ Hegel, Phänomenologie des Geistes, 29; Phenomenology of Mind, 21 (trans. modified).

${ }^{51}$ Hegel, Phänomenologie des Geistes, 30; Phenomenology of Mind, 21.
} 
Heidegger sees as a point of culmination in the history of Western "ontotheological" metaphysics. ${ }^{52}$ "Ontotheology" here designates the Platonic and Aristotelian foundationalist approach in which the ontological question concerning being qua being — that which determines everything that is insofar as it is - is considered in terms of the ideal, supreme, and perfect, "divine" (theion), manifestation or instance of being. For Plato, this is the Idea of the Good, for Aristotle, the metaphysical divinity as the perfectly actualized, simple, and identical substance. ${ }^{53}$ In Hegel's Phenomenology, the experience of consciousness is the process of the spirit's unfolding presence to itself-the unfolding of the fundamental and ultimate level of meaningful reality, which Hegel ultimately understands as the selfconsciousness of absolute subjectivity, as the subjectity or subjectness (Subjektität) of all conscious subjects. As Heidegger interprets it, the "experience" articulated in The Phenomenology of Spirit is the process by which this absolute comes to be "with us" (bei uns), by which it gradually sheds its transcendence with regard to finite knowledge and becomes accessible to "us," to finite subjectivity. The absolute reveals itself as the absoluteness inherent in subjectivity itself-as the intelligible and rational, conceptual and discursive structure that comprehends everything that is. ${ }^{54}$ As the coming-

52 On Hegel as the "completion" (Vollendung) of ontotheological metaphysics, see, e.g., Martin Heidegger, “Überwindung der Metaphysik" [1936-46], in Vorträge und Aufsätze, 9th ed. (Stuttgart: Neske, 2000), 72; "Overcoming Metaphysics," in The End of Philosophy, trans. Joan Stambaugh (New York: Harper \& Row, 1973), 89; "Der europäische Nihilismus" [1940], in Nietzsche, vol. 2, 6th ed. (Stuttgart: Neske, 1998), 177-180; “European Nihilism," in Nietzsche, vol. 4: Nihilism, trans. Frank A. Capuzzi, ed. David Farrell Krell (San Francisco: HarperSanFrancisco, 1991), 147-149; “Hegels Begriff der Erfahrung” [1942], in Holzwege, ed. Friedrich-Wilhelm von Herrmann, 8th ed. (Frankfurt am Main: Klostermann, 2003), 192-203; “Hegel's Concept of Experience," in Off the Beaten Track, trans. Julian Young and Kenneth Haynes (Cambridge: Cambridge University Press, 2002), 144-152; “Brief über den ‘Humanismus' ” [1946], in Wegmarken, ed. Friedrich-Wilhelm von Herrmann, 3rd ed. (Frankfurt am Main: Klostermann, 1996), 335-336; “Letter on 'Humanism'," trans. Frank A. Capuzzi, in Pathmarks, ed. William McNeill (Cambridge: Cambridge University Press, 1998), 255256; “Die onto-theo-logische Verfassung der Metaphysik" [1957], in Identität und Differenz [1957], 12th ed. (Stuttgart: Klett-Cotta, 2002), 31-67; "The Onto-theo-logical Constitution of Metaphysics," in Identity and Difference, trans. Joan Stambaugh (New York: Harper \& Row, 1969), 42-74; “Hegel und die Griechen” [1958], in Wegmarken, 432-433; “Hegel and the Greeks," trans. Robert Metcalf, in Pathmarks, 327.

53 On ontotheology, see, e.g., Martin Heidegger, "Die seinsgeschichtliche Bestimmung des Nihilismus" [194446], in Nietzsche, vol. 2, 311-315; "Nihilism as Determined by the History of Being," in Nietzsche, vol. 4: Nihilism, 207-210; “Die onto-theo-logische Verfassung," 31-67; “The Onto-theo-logical Constitution,” 42-74. ${ }^{54}$ Heidegger, “Hegels Begriff der Erfahrung," 202-204; “Hegel's Concept of Experience,” 151-153. 
into-presence, the Parousia, of the absolute, Hegelian "[e]xperience is that being [Sein] in accordance with which the absolute wills to be with us." 55

Once the experience of consciousness is completed in absolute knowledge and the absolute thus becomes accessible within the immanence of self-consciousness, ontotheology has reached its fullest possible extent. Heidegger's later thought, following his Contributions to Philosophy (1936-38), was centered on exploring his notion of the contemporary possibility of another beginning or inception (Anfang) — a new, postontotheological starting point for a postmetaphysical, radically hermeneutic thinking that would call into question certain fundamental presuppositions of the Presocratic and Platonic "first beginning" of Western metaphysics. ${ }^{56}$ In contrast to the ontotheological drive toward an absolute point of view, postmetaphysical thinking would embrace the finitude, that is, the temporal and spatial situatedness and the historical, cultural, and linguistic context-sensitivity of human thought-more specifically, of the dynamic and reciprocal correlation between the human being and being that the later Heidegger captures in the title Ereignis, "event."

Gadamer's outline of a hermeneutic concept of experience should be understood in the context of this Heideggerian break with ontotheology that renounces the Hegelian teleological aspiration to an absolute and infinite grasp of being in the sense of the accessibility and intelligibility of beings. Gadamer's particular contribution in this regard is his attempt to reappropriate the concept of experience for a radical hermeneutic philosophy of the irreducibly historical and interpretive character of all understanding. The resources for this reappropriation can be found within the philosophical history of the concept of experience itself, in the intrinsic dimensions of experience that the epistemological tradition certainly acknowledged but regarded as weaknesses or deficiencies that must be overcome by truly scientific thinking: (1) its contingency, that is, its essentially uncontrollable and unrepeatable nature; (2) its singularity or situated particularity, that is, its irreducible relativity to individual experiential situations with their varying prejudices and expectations; and (3)

\footnotetext{
${ }^{55}$ Heidegger, "Hegels Begriff der Erfahrung," 204; “Hegel's Concept of Experience," 153 (trans. modified).

56 On the "other inception" (der andere Anfang), see, e.g., Martin Heidegger, Beiträge zur Philosophie (Vom Ereignis) [1936-38], ed. Friedrich-Wilhelm von Herrmann, Gesamtausgabe, vol. 65 (Frankfurt am Main: Klostermann, 1989); 4-6, 55, 57-60, 167-224; Contributions to Philosophy (Of the Event), trans. Richard Rojcewicz and Daniela Vallega-Neu (Bloomington, IN: Indiana University Press, 2012), 6-8, 44-45, 46-48, 131-176; Grundfragen der Philosophie: Ausgewählte "Probleme" der "Logik" [1937-38], ed. Friedrich-Wilhelm von Herrmann, 2nd ed., Gesamtausgabe, vol. 45 (Frankfurt am Main: Klostermann, 1992), 124-125, 184-190; Basic Questions of Philosophy: Selected "Problems" of "Logic", trans. Richard Rojcewicz and André Schuwer (Bloomington, IN: Indiana University Press, 1994), 108-109, 158-164.
} 
its negativity, that is, its potential for undermining and transforming all pre-established judgments and cognitive frameworks. As we have seen, the Aristotelian, Baconian, and Hegelian notions of experience as a method, as a pathway to science, all sought to immunize scientific knowledge against these aspects of experience by envisioning a transition from experience to the most universal and fundamental intuitive principles or axioms of intelligibility, to the discovery of the hidden truths or essences of nature through the systematic experimental management of empirical data, or to the absolute self-consciousness in which there is no longer any disparity between knowledge and its object. In other words, all three thinkers of the tradition ultimately seek to attain, through experience, a kind of knowledge that is no longer susceptible to experience.

Gadamerian philosophical hermeneutics, by contrast, discovers the true hermeneutic fruitfulness of experience in precisely these aspects. Hermeneutic experience is historical experience enacted in singular historical situations of meaningfulness. Such situations are, as articulated in Truth and Method, always entered in terms of our individual prejudices, of a pre-existing cultural understanding, of discourses and conceptual and linguistic frameworks inherited from our tradition. ${ }^{57}$ When making sense of any meaningful phenomenon encountered in the situation, we primarily interpret it in terms of our preunderstanding, applying the discourses and concepts that we already possess. However, according to the Heideggerian and Gadamerian model of the hermeneutic circle, if approached in a proper manner-in the form of a genuine question that acknowledges the finitude of our knowledge - these phenomena can, in turn, work retroactively on our preunderstanding and disclose its insufficiency, its inability to make sense of certain aspects of what is read, heard, or encountered. ${ }^{58}$ This discovery of insufficiency then encourages us to reconsider and revise our prejudices, our existing conceptual framework-and it is precisely this feature that makes this discovery an "experience." In the context of the hermeneutic circle, the capacity for experience is precisely the capacity for being tested and "imperiled" by situations of interpretation in unpredictable ways, for encountering the irreducible negative otherness in phenomena that our current preunderstanding and our current conceptual framework are in some respect inadequate for making sense of. Thus, openness to hermeneutic experience means accepting, ever anew, the necessity of

\footnotetext{
${ }^{57}$ Gadamer, Wahrheit und Methode, 270-312; Truth and Method, 268-306.

${ }_{58}$ On the hermeneutic circle, see Martin Heidegger, Sein und Zeit [1927], 18th ed. (Tübingen: Niemeyer, 2001), 150-153; Being and Time, trans. Joan Stambaugh, revised by Dennis J. Schmidt (Albany, NY: State University of New York Press, 2010), 145-149; Gadamer, Wahrheit und Methode, 270-281; Truth and Method, 268-278. On the hermeneutic priority of the question, see Gadamer, Wahrheit und Methode, 368-384; Truth and Method, 356371.
} 
undergoing a transformation, of reconsidering and revising our current mode and our current discursive tools for understanding, interpreting, and making sense.

In this sense, as Gadamer points out, a truly meaningful—that is, transformative-experience is analogous to an encounter with another person in the second person singular, as a "thou" (Du) with whom we are engaged in a genuine conversation. A "thou" always carries a foreign element irreducible to the "I" and therefore can never, in an encounter that takes place within the ethical dimension, be a simple object. Interpreting a text, a discourse belonging to a textual tradition, cannot be carried out in the role of an impassive and neutral observer-it always compels the interpreter to engage, from out of her specific historical and discursive position, with another "speaker," another historical and discursive position which, if genuinely questioned and properly "listened" to, cannot avoid affecting the questioner herself. This is the Gadamerian model of "historically effected consciousness" (wirkungsgeschichtliches Bewußtsein), a consciousness of history not as a mere object of study but as the living network of a tradition within which we ourselves are caught and involved. ${ }^{59}$ Through a transformative discursive exchange with the "thou," we can ultimately become incorporated into a new "we," an entirely new shared perspective on the world. In such a hermeneutic "fusion of horizons" (Horizontverschmelzung), which is something entirely novel with regard to the horizons fused in it, our self is irreparably transformed. ${ }^{60}$ But only a finite self can encounter another as a genuine "thou"; only a finite self is susceptible to contingent, singular, and transformative encounters with that which comes from beyond its proper realm, in other words, to experiences. "Hermeneutic consciousness culminates not in methodological sureness of itself, but in the same readiness for experience that distinguishes the experienced person from the one captivated by dogma." 61

Among more recent contributions to the theory of hermeneutic experience, the subtle account articulated in Claude Romano's Event and World (1998) approaches experience as exposure to events, to the singular takings-place of meaningfulness that have no substantial and repeatable identity. These events are precisely moments of transformation and rupture with previous identities after which nothing has exactly the same meaning as it did before. ${ }^{62}$ This singularity and unrepeatability of the events of experience is the fundamental reason, that experience, unlike technical expertise, cannot be taught to others, as Aristotle emphasized: experience only truly addresses us in the singular.

\footnotetext{
${ }^{59}$ Gadamer, Wahrheit und Methode, 363-368; Truth and Method, 352-355.

${ }^{60}$ Gadamer, Wahrheit und Methode, 311-312, 380, 383, 392; Truth and Method, 305-306, 367, 370, 390.

${ }^{61}$ Gadamer, Wahrheit und Methode, 367-368; Truth and Method, 355.

${ }^{62}$ Romano, L'événement et le monde, 193-255; Event and World, 143-189.
} 
" $[\mathrm{N}]$ obody can teach their experience to another, for the experience they teach is always their own." While "[o]nly events teach in the strict sense," they do not transmit any knowledge or even empirical data. Experiences only teach us "to unlearn, to undo our prior knowledge and certitudes, by holding ourselves ready to learn anew from events themselves." 63 They hold us open to the "non-sense" inherent in every meaningful encounter with reality, to the inexhaustible excess of meaningfulness that always makes our comprehension or grasp of the situation inevitably finite and partial. ${ }^{64}$ Ex-perience, hyphenated by Romano in order to highlight the root *per-, is fundamentally an encounter with one's limits, one's essential finitude. In this sense, the limit-experiences of suffering and mortalityencounters with the limits of our physical and mental capacity to endure reality as well as the essential temporal limitedness and inescapable incompleteness of our capacity for meaningful encounters in general-are experiences par excellence. ${ }^{65}$

All in all, we see that even hermeneutic experience is "methodical" in the sense of being a dialectical process of transformation and development; but it is a dialectic without ultimate reconciliation, a method without teleology, without end or telos, a path followed indefinitely for its own sake in order to keep our thinking alive. As recapitulated by Gadamer, hermeneutic experience is

experience of human finitude [Endlichkeit]. The truly experienced person [Erfahren] is one who has taken this to heart, who knows that she is master neither of time nor the future.... Genuine experience is that whereby the human being becomes aware of her finitude. In it are discovered the limits of the power and the self-knowledge of her planning reason. ... Genuine experience is experience of one's own historicity [Geschichtlichkeit]. ${ }^{66}$

\footnotetext{
${ }^{63}$ Romano, L'événement et le monde, 199; Event and World, 147.

${ }^{64}$ Romano, L'événement et le monde, 208-209; Event and World, 154-155.

${ }^{65}$ Romano, L'événement et le monde, 233-255; Event and World, 173-189.

${ }^{66}$ Gadamer, Wahrheit und Methode, 363; Truth and Method, 351 (trans. modified).
} 